\title{
Endralazine in patients with severe hypertension and renal insufficiency
}

\author{
E. R. HIGGS \\ B.M., B.Ch., M.R.C.P. \\ R. A. BANKS \\ B.Sc., M.B., M.R.C.P.
}

P. R. HARRISON

M.B., M.R.C.P.

J. C. KINGSWOOD

M.B., M.R.C.P.

\author{
J. C. MACKENZIE
}

M.B. F.R.C.P.E.

Department of Nephrology, Southmead Hospital, Bristol

\begin{abstract}
Summary
Endralazine, a new peripheral vasodilator, was given in conjunction with a beta-blocker to 21 patients with hypertension and chronic renal failure. All subjects were either poorly controlled on their previous antihypertensive regime or were experiencing unacceptable adverse effects from drugs. After 4 weeks blood pressure was reduced in all patients and symptomatic side effects were few. Two patients became anti-nuclear factor (ANF) positive in weak titre but without evidence of the lupus syndrome.
\end{abstract}

\section{Introduction}

Current management of hypertension in patients with renal impairment is often unsatisfactory and associated with unacceptable adverse effects from drugs. Endralazine is a new peripheral vasodilator chemically related to hydralazine but not dependent upon acetylation for its metabolism (Salzmann, 1973; Baldeck and Kalberer, 1978). The present study describes our experience with endralazine after one month in 21 patients with uncontrolled hypertension and chronic renal failure.

\section{Patients and methods}

Twenty-one patients who were attending the Renal Clinic at Southmead Hospital were studied. Their underlying renal disease is listed in the Table. The study had been approved by the Research and Ethical Committee of the hospital and all patients gave informed written consent. Hypertension was either unconitrolled on a maximum dose of betaadrenergic blocking drugs (diastolic pressure $\geqslant 107$ $\mathrm{mmHg}$ ) or patients were experiencing unacceptable adverse effects with additional drugs. Thirteen patients were taking three or more antihypertensive drugs. All 21 patients had stable chronic renal failure (creatinine clearance $23-86 \mathrm{ml} / \mathrm{min}$ ). Five had received a cadaveric renal transplant and were receiving daily prednisolone and azathioprine (creatinine clearance $28-75 \mathrm{ml} / \mathrm{min}$ ). Pregnancy, severe liver disease, renal failure requiring haemodialysis, and a positive ANF excluded entry to the study.

Before entering the study, patients were assessed clinically for evidence of cardiovascular disease. Blood pressure and heart rate were measured with the patient lying and $2 \mathrm{~min}$ after standing. Blood pressure was measured with a standard mercury sphygmomanometer and was calculated as the mean of two or three measurements at intervals of one minute. All measurements were made by the same investigator (ERH), the diastolic pressure being recorded as Korotokoff phase 4.

Measurements of renal function were performed weekly and consisted of blood urea, serum creatinine, creatinine clearance, $24 \mathrm{hr}$ protein excretion and plasma electrolytes. In addition, blood haemoglobin, white blood cell count, plasma viscosity, blood sugar and liver function tests were recorded at the beginning and end of the study. The presence of DNA binding and ANF was also established before and at the end of the study, as was the acetylator status of each subject using the method of Price-Evans (1969). Electrocardiograms were recorded weekly and assessed for ischaemic changes.

\section{Trial design}

Antihypertensive drugs other than beta-adrenergic blockers and (in 13 patients) diuretics were discontinued on the first study day. On Day 1, following clinical assessment, patients received endralazine 2.5 $\mathrm{mg}$ by mouth. If there were no adverse effects in the 
TABLE 1. Patient data before and after 4 weeks endralazine

\begin{tabular}{|c|c|c|c|c|c|c|c|}
\hline \multirow{2}{*}{$\begin{array}{l}\text { Patient No/ } \\
\text { age/sex }\end{array}$} & \multirow[b]{2}{*}{ Renal disease } & \multirow{2}{*}{$\begin{array}{l}\text { Drugs before study } \\
\text { (excluding beta-blocker) }\end{array}$} & \multicolumn{2}{|c|}{$\begin{array}{c}\text { Plasma } \\
\text { creatinine } \\
(\mu \mathrm{mol} / \mathrm{litre})\end{array}$} & \multirow{2}{*}{$\begin{array}{l}\text { ANF† } \\
\text { After }\end{array}$} & \multicolumn{2}{|c|}{$\begin{array}{c}\text { DNA } \\
\text { binding } \\
\text { (units/ml) }\end{array}$} \\
\hline & & & Before & After & & Before & After \\
\hline $1 / 55 / \mathbf{M}$ & Polycystic kidneys & B & 201 & 198 & neg & 19 & 14 \\
\hline $2 / 61 / \mathrm{M}$ & Polycystic kidneys & B, $\mathrm{H}$ & 212 & 158 & neg & 9 & 18 \\
\hline $3 / 61 / F$ & Chronic pyelonephritis & $\mathbf{H}$ & 150 & 169 & neg & 20 & 17 \\
\hline $4 / 65 / F$ & Chronic interstitial nephritis & & 152 & 158 & neg & 25 & 20 \\
\hline $5 / 57 / \mathrm{F}$ & Calculus renal disease & & 239 & 240 & $1 / 100$ & 39 & 20 \\
\hline $6 / 59 / \mathrm{M}$ & Chronic pyelonephritis & B, $\mathrm{H}$ & 177 & 140 & neg & 17 & 15 \\
\hline $7 / 50 / \mathbf{M}$ & Chronic glomerulonephritis & B, $\mathrm{H}$ & 139 & 141 & neg & 42 & 40 \\
\hline $8 / 60 / \mathrm{F}$ & Hypertensive nephrosclerosis & F, MD & 131 & 100 & neg & 14 & 56 \\
\hline 9/35/M & Hypertensive nephrosclerosis & $\mathbf{F}, \mathbf{M}$ & 134 & - & - & 21 & - \\
\hline $10 / 50 / \mathrm{M}$ & Chronic glomerulonephritis* & $\mathrm{F}, \mathrm{M}$ & 216 & 185 & neg & 10 & 26 \\
\hline $11 / 46 / \mathrm{M}$ & Chronic pyelonephritis* & $\mathrm{H}, \mathrm{MD}$ & 136 & 128 & neg & 32 & 34 \\
\hline $12 / 46 / \mathrm{M}$ & Chronic glomerulonephritis* & $\mathrm{H}$ & 154 & 138 & neg & 23 & 40 \\
\hline $13 / 13 / \mathrm{M}$ & Congenital ureteric reflux & $\mathrm{F}, \mathrm{M}$ & 117 & 92 & neg & 43 & 13 \\
\hline $14 / 41 / M$ & Polycystic kidneys & B, $\mathrm{H}$ & 320 & 351 & neg & 48 & 26 \\
\hline $15 / 59 / \mathrm{M}$ & Chronic glomerulonephritis & Mo, $\mathrm{H}$ & 154 & 156 & $1 / 100$ & 25 & 32 \\
\hline $16 / 34 / M$ & Diabetic nephropathy & & 150 & 132 & neg & 13 & 6 \\
\hline $17 / 46 / \mathrm{M}$ & Polycystic kidneys & B & 236 & 259 & neg & 17 & 6 \\
\hline $18 / 55 / \mathrm{M}$ & Chronic glomerulnephritis & F, D & 169 & 146 & neg & 12 & 17 \\
\hline 19/44/M & Chronic glomerulnephritis & B, $\mathrm{H}$ & 397 & 370 & neg & 39 & 72 \\
\hline $20 / 17 / M$ & Congenital ureteric reflux ${ }^{*}$ & $\mathbf{H}$ & 117 & 294 & neg & 18 & - \\
\hline $21 / 30 / \mathrm{M}$ & Congenital ureteric reflux & B, H, MD & 230 & 243 & neg & 50 & 30 \\
\hline
\end{tabular}

* = Functioning renal allograft; †All negative before endralazine.

Drug code: $\mathrm{B}=$ bendrofluazide; $\mathrm{H}=$ hydralazine; $\mathrm{MD}=$ methyldopa; $\mathrm{F}=$ frusemide; $\mathrm{M}=$ minoxidil; $\mathrm{Mo}=$ Moduretic; $\mathrm{D}=$ diazoxide.

first $3 \mathrm{hr}$, they were continued on $2.5 \mathrm{mg}$ three times daily. On Day 3, this was increased to $5 \mathrm{mg}$ three times daily and subsequently on days 5,7 and 10 by further increments of $5 \mathrm{mg}$ to a total dose of $20 \mathrm{mg}$ three times daily or until a satisfactory control of blood pressure was achieved (diastolic $\leqslant 102 \mathrm{mmHg}$ ).

\section{Results}

One patient (no. 9) was withdrawn after 2 weeks for failing to comply with the drug regime and this precipitated hypertensive heart failure. His results have not been included in the study.

Renal function was not affected significantly, although there was a tendency for serum creatinine to fall over the course of the study (Table 1).

The Figure shows the mean systolic and diastolic blood pressure and heart rate before and after the addition of endralazine in 20 patients. Nineteen patients had a reduction in lying and standing blood pressure. Final daily dose of endralazine was 7.5 or $15 \mathrm{mg}$ ( 12 patients) and 30 or $45 \mathrm{mg}$ ( 7 patients). Only one patient received $60 \mathrm{mg}$ daily. Three patients failed to achieve acceptable blood pressure control at the end of the study. Patient 10 had a functional renal allograft and hypertension resistant to minoxidil. Subsequently he had a bilateral host nephrectomy but is now taking labetalol $600 \mathrm{mg}$ a day with a blood pressure of $180 / 110 \mathrm{mmHg}$ lying and standing. $\mathrm{He}$ is reluctant to start minoxidil because of previous fluid retention. Patient 14, who had already suffered a cerebrovascular accident in association with hypertension had a blood pressure of $175 / 132 \mathrm{mmHg}$ while taking hydralazine, oxprenolol and bendrofluazide. After one month blood pressure control was not improved by the substitution of endralazine $45 \mathrm{mg}$ ? daily. Subsequently he was successfully treated with minoxidil but at the expense of hypertrichosis and a 6 $\mathrm{kg}$ fluid weight gain. In patient 18 , diastolic pressure was not reduced below $105 \mathrm{mmHg}$ by endralazine. However, he was able to discontinue the oral hypoglycaemic agent and most of the frusemide necessitated by his previous regime which included diazoxide.

Two patients became ANF positive by the end of the study, but with no clinical evidence of the lupus syndrome, and no significant rise in DNA binding (Table 1); both were taking $15 \mathrm{mg}$ of endralazine daily. They have continued to be followed up, and at 6 months there has been no change in their titre of ANF and no adverse clinical effects have been seen. Neither patient was on any other drug known to produce a positive ANF. Patient 5 was a slow, and patient 15 a fast acetylator, acetylating less than and greater than $30 \%$ of an oral dose of sulphadimidine respectively.

The side effects which were mild and self-limiting consisted in four patients of tiredness, in three of facial flushing and headache (lasting approximately one week) and in one of unexplained vomiting during the first week of taking endralazine. Patient 12 had transient leucopenia during the study due to 
cytomegalovirus infection in association with renal transplantation. This improved with reduction of his azathioprine. There was no evidence of hepatic or renal toxicity or any other laboratory or clinical abnormality. Mean body weight was unaffected by endralazine and no patient became clinically oedematous.

\section{Discussion}

Hypertension is a common problem in patients with renal impairment, which if inadequately controlled can lead to a more rapid decline in the patient's renal function (Moyer et al., 1956). Treatment in these patients can be difficult because of the severity of the hypertension and the side effects of current drug regimes. The vasodilator hydralazine is in common use in the treatment of hypertension resistant to diuretics and beta-blockers. However, hydralazine often causes unpleasant haemodynamic symptoms such as headache and postural hypotension. Treatment with hydralazine is associated with seroconversion of antinuclear factor and, more rarely, development of a lupus-like syndrome (Perry, 1973). This effect is related to exposure to free drug and the major excretion of hydralazine is as the acetylated metabolite. Patients who acetylate the drug slowly are therefore those most at risk of developing this adverse effect (Perry et al., 1970; Bing et al., 1980). The present study has examined a new vasodilator, endralazine which is chemically related to hydralazine but for which acetylation is not a major route of metabolism (Baldeck and Kalberer, 1978).

Twenty-one patients entered the study and one was withdrawn after 2 weeks for failing to comply with regular drug taking. At the end of one month all but one patient had a reduction in lying and standing systolic and diastolic blood pressure while taking endralazine $7.5 \mathrm{mg}$ to $60 \mathrm{mg}$ daily in conjunction with beta-adrenergic blocker. Before the study nine patients were taking hydralazine, three minoxidil, one diazoxide and three methyldopa. None of these patients has had to return to their previous drugs while receiving endralazine. There was no postural hypotension and no change in pulse rate after endralazine. Those patients previously treated with methyldopa or minoxidil felt better than on their previous drug regime. Patient 14 failed to respond adequately to endralazine and is now controlled with minoxidil. Fluid weight gain is however only partially controlled with frusemide and he feels less well.

The dose of endralazine required to produce adequate blood pressure control was not dependent on the initial level of blood pressure nor the overall renal function.

Though two patients became ANF positive at a

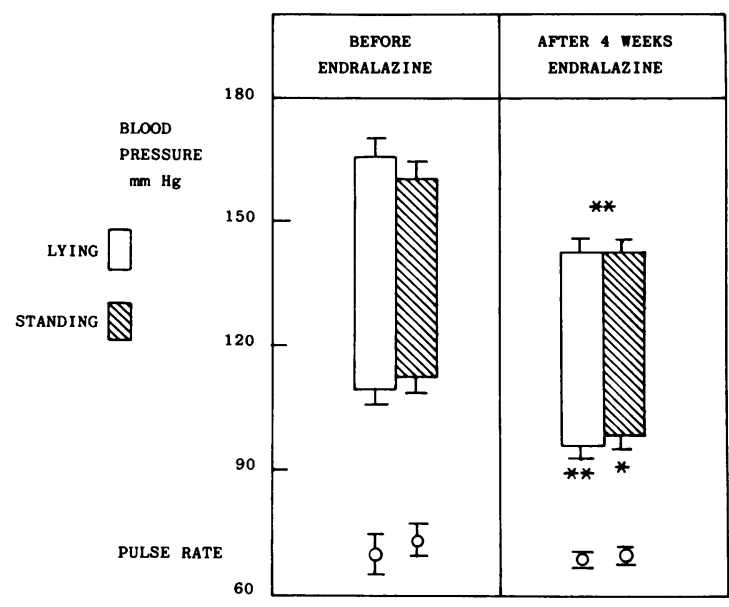

FIG. 1. Mean ( \pm s.e.m.) blood pressure and pulse rate/minute before and after endralazine.

${ }^{*} P<0.005$

$* * P<0.001\}$ before $v r$ after paired Student's $t$-test

titre of $1 / 100$ during the study, there were no clinical signs of development of lupus syndrome and their DNA binding did not rise significantly. There was no correlation in the two patients with acetylator status, patient 5 being a slow and patient 15 a fast acetylator. At 6 months follow up of three patients none has developed any evidence of a lupus syndrome and the titre of ANF has remained low. The significance of these observations thus remains uncertain.

Though endralazine is a potent vasodilator, oedema and weight gain were not seen in this study. Severe symptomatic side effects did not develop during the 4 weeks of the study and have not been apparent in those patients who have continued therapy for up to 6 months. Fourteen patients in the study who had had troublesome side effects with their previous regime felt so well while taking endralazine that they have asked to be continued on the drug. We conclude that endralazine is a potent antihypertensive drug when used in conjunction with beta-adrenergic blockage. Further long-term studies are in progress.

\section{Acknowledgments}

We thank Miss Kathryn Edmonds for typing the manuscript and Dr R. A. Banks for assistance in its preparation. Sandoz Products Ltd supplied endralazine.

\section{References}

BALDECK, J.P. \& KALBERER, F. (1978) ${ }^{14} \mathrm{C}$ BQ-22-708, Internal Report. Metabismus bein Menschen. Sandoz Ltd, Basle, 2.11.78. Bing, R.F., RuSSElL, G.L., Thurston, H. \& Swales, J.D. (1980) Hydralazine in hypertension: is there a safe dose? British Medical Journal, 2, 353. 
Moyer, J.H., Herder, C., Pevey, K. \& Ford, R.V. (1956) The effect of treatment on the vascular deterioration associated with hypertension with particular emphasis on renal function. American Journal of Medicine, 24, 177.

PERRY, H.M. (1973) Late toxicity due to hydralazine resembling systemic lupus erythematosus or rheumatoid arthritis. American Journal of Medicine, 54, 58.

Perry, H.M., TAN, E.M., Carmody, S. \& SaKamoto, A. (1970)
Relationship of acetyl transferase activity and antinuclear antibodies and toxic symptoms in hypertensive patients with hydralazine. Journal of Laboratory and Clinical Medicine, 76, 114.

Price-Evans, D.A. (1969) An improved and simplified method of detecting the acetylator phenotype. Journal of Medical Genetics, 6 , 405.

SalzMANN, R. (1973) The pharmacology of BQ-22-708 (antihypertensive). Pharmacological Exposé. Sandoz Ltd, Basle, 24.9.73. 